\title{
Using Bagasse as a natural adsorbent for aflatoxins in rabbit diets
}

T. S. Abdel- ghany ${ }^{\prime}$ H. A. E.Abou-ead² M.S.M. Abousekken² ، Amal A. Abou Hagar³

1- Regional Centre for food and feeds, Agriculture Research Centre, Giza, Egypt

2, Environmental Studies and Research Institute, University of Sadat City,

\section{ABSTRACT}

Thirty males growing White New Zealand (WNZ) rabbits of Aged 4 weeks with initial mean weight $(750 \pm 50 \mathrm{~g})$ were divided into 5 equal groups were kept under the same managerial conditions were conducted to determine the effect of feeding dietary bagasse as a source of natural dietary fiber and to adsorbent for aflatoxins or natural contamination in rabbit diets and to evaluate of using dietary bagasse on growth performance of rabbits. The results obtained were : Group fed basal diet supplemented with bagasse at level $6 \%$ (T3,) recorded the best LBW (2279.2g) followed by group fed diet supplemented low dose of AFs + bagasse at level 6\% (T5) being (2177.5 g) ,meanwhile, group fed basal diet (control ) (T1) was the worst one being $(2087 \mathrm{~g})$; group fed dietary bagasse at level $6 \%$ and low dose of AFs (75.0ppb) (T5) achieved significantly $(\mathrm{P}<0.05)$ the highest $(\mathrm{TG})$ value $(1402.0 \mathrm{~g})$; rabbits group fed $6 \%$ bagasse and groups fed $6 \%$ bagasse with Low aflatoxin dose (75.0ppb) significantly $(\mathrm{P}<0.05)$ consumed TFI less than control and other experimental groups; No significant differences $(\mathrm{p}<0.05)$ were found among TFCR and Adsorption abilities ranged from 94.63-98.10\% the highest adsorption capacity was observed when using $6 \%$ bagasse and $3 \mathrm{hr}$ shaking time at low TAF concentration, while the lowest value of binding was obtained at level $3 \%$ bagasse and $1 \mathrm{hr}$ shaking time and high TAF concentration. The study concluded that using dietary $6 \%$ bagasse with Low aflatoxin dose $(75.0 \mathrm{ppb})$ in growing rabbit diets significantly improve growth performance and have Adsorption ability at low TAF concentration.

Key words: Growing rabbits- aflatoxin - Adsorption - bagasse - growth performance

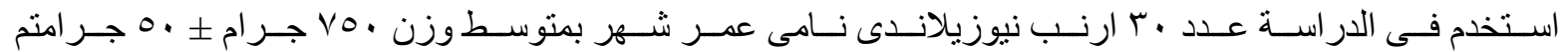

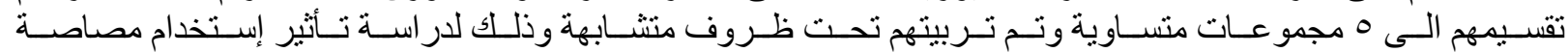

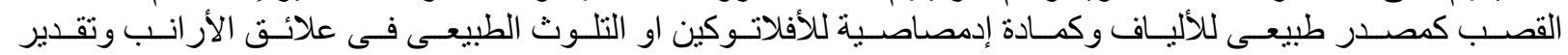

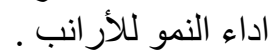

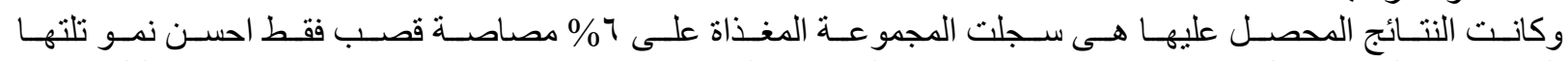

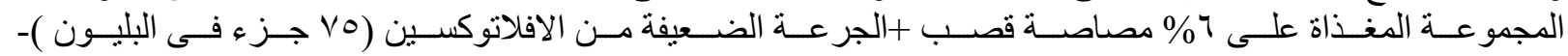

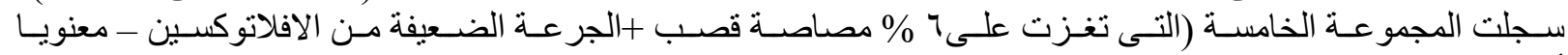

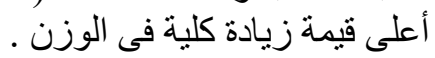

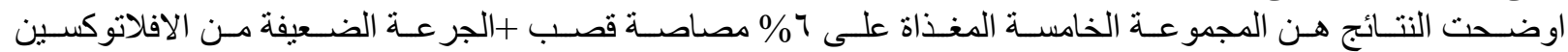

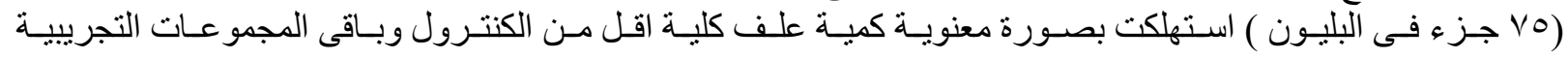

$$
\text { اوضحت النتائج انة لا يوجد اختلافات معنوية فى معامل التحويل الغذائى بين المجمو عات التجريبية . }
$$




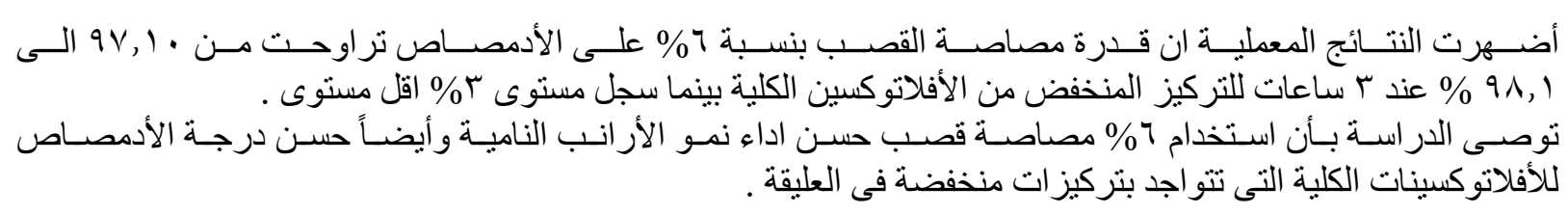

\section{INTRODUCTION}

Aflatoxins are a group of secondary fungal metabolites - also known as mycotoxins - which are produced by fungi of the Aspergillus genus, particularly $A$. flavus (Saladino et al. 2016). Aflatoxin B1, is the most commonly occurring and potent of the aflatoxins is associated with a specific AGG to AGT amino acid Trans version mutation at codon 249 of the p53 gene in human HCC, providing mechanistic support to a causal link between exposure and disease (Wu and Khlangwiset, 2010). Evidence of acute aflatoxicosis in humans has been reported worldwide especially in the third world countries like Taiwan, Uganda, India, Kenya and many others (USAID, 2012). Various strains isolated of fungi can produce AFs such as A. flavus, A. parasiticus, A. oryzae, A. tamari, A. flavus Var. columnaris and A. parasiticus Var. globosus (Raper and Fennell, 1965). Cereal grains, such as wheat and rice, in general, appear to be a good substrate for toxin production than the oilseeds such as cottonseed, soybean and peanuts (Diener and Davis, 1968). The fungi, which produce AFs, can be grouped into three classes according to their moisture requirements. The first class contains the field fungi, which need 22-25\% moisture. The second includes storage fungi, which need 13-18\% moisture and the third, which is the advanced decay fungi, require over $18 \%$ moisture (Christensen, 1965).Mycotoxins destroy the tissues by oxidizing proteins and most of them have immunosuppressive effects (Kumar et al., 2008). Rabbits are highly susceptible to aflatoxins which are produced by Aspergillus molds. The median lethal dose (LD50) of aflatoxin B1 (AFB1) in rabbits was determined as a single oral dose of $300 \mathrm{mg} / \mathrm{kg}$ bodyweight (BW) (Cardona et al., 1991). However AFB1 as low as $15 \mathrm{mg} / \mathrm{kg}$ feed caused high levels of morbidity and mortality (Makkar and Singh, 1991).Aflatoxins have been reported to cause liver cirrhosis as well as liver cancers (USAID, 2012 \& Thrasher, 2012) Aflatoxins have also been reported to cause serious acute effects on the GIT ( Gursoy et al., 2008). World sugarcane production was estimated to be around1.91 Gt in 2013, about $0.77 \mathrm{Gt}$ produced in Brazil alone, with an average productivity of $75 \mathrm{t}$ ha_1 .During the harvest of sugarcane, the leaves and tops are left infield, whereas the stalks are transported to the mill where they are crushed to extract the sugar juice for the production of sugar and ethanol. Two major residues are produced by the sugarcane industry, the fibrous fraction following juice extraction (named bagasse), and the harvest residue (straw). These wastes are produced in large quantities, about 280 million metric tons of bagasse and straw per year, and they are expected to increase in the near future as this crop expands and new industrial plants are brought online (José et al., 2015). Processed bagasse is added to human food as sugar cane fiber. It is a soluble fiber but can help promote intestinal regularity. One animal study suggests that sugar cane fiber combined with a high fat diet may help control type 2 diabetes. Bagasse is a good source of lignoceric and cerotic acids (Kamal G. Nath., 2011). On the dry weight basis, bagasse is primarily composed of 
cellulose (40-50\%), hemicellulose (30-35\%), and lignin (20-30\%) (Amin, 2011). In Egypt, there is a wide gap between animal requirements and the available feedstuffs. Also, the rapid increase in the cost of animal protein source has get now an urgent need to increase livestock. This brings the rabbits into focus, as it forms a very important aspect of livelihood for socio economic reasons. Rabbit production has been noted to be one of the best means of alleviating the prevailing low animal protein consumption in developing countries due to certain characteristic of rabbits and rabbit meat ( Maidala and Istifanus, 2012). The immune system consists of two main components: cellular and humoral. The immunoglobulin's or/and antibodies of humoral immunity are mainly concentrated on gamma globulins which are serum proteins with c mobility in electrophoresis (Hegazy and El-Faramawy (2001).

\section{MATERIALS AND METHODS}

The present experiment was carried out at farm of Sustainable Development Department, Environmental Studies and Research Institute, University of Sadat City, Menufiya governorate, Egypt during January to March, 2017. The laboratory work was done and Regional Center for food and feeds, Agriculture Research Center. The objective of this research is to determine the effect of feeding dietary bagasse as a source of natural dietary fiber ingredient and to adsorbent for aflatoxins or natural contamination in rabbit diets and to evaluate recent information of using dietary bagasse on growth performance of growing New Zealand White rabbits.

All chemicals were of analytical grade. Chemicals and Solvent were purchased from Merck (Darmstadt, Germany). Aspergillus flavus NRRL (3145) was obtained from the National Research Center (Dokki , Giza). St. Aflatoxins (B1, B2, $\mathrm{G}_{1}$ and $\mathrm{G}_{2}$ ) were obtained from Sigma Chemical Company (St Louis, MO, USA).

Fungal growth Inoculum was prepared by incubating Potato Dextrose Agar (PDA) slant tubes $(1.5 \times 15 \mathrm{~cm})$ inoculated with $A$. flavus spores for 7 to 21 days at $28^{\circ} \mathrm{C}$. Spores of 10 -day old (A. flavus culture) were scrapped loose with a loop after adding $3 \mathrm{ml}$ sterile distilled water to each slant (Shotwell et al., 1966). The Spores scraped by adding sterile distilled water to the surface growth on agar slant and an aliquot amount from the resulting spore suspension ( $1 \mathrm{ml}$ ) added to conical flasks (2liters) containing yeast extract media. Mycelial mats after 10 -day incubation at $30^{\circ} \mathrm{C}$ were broken with a glass rod and collected by filtration through filter paper. Culture filtrates (mother solution) were extracted with chloroform $(1: 2, \mathrm{v} / \mathrm{v})$.

Bagasse was obtained from local juice stores. Oven drying was done in a cabinet oven with air circulation at $60 \mathrm{C}^{\circ}$ overnight whereas dried bagasse was milled by laboratory mill to pass a $2.0 \mathrm{~mm}$ size mish pares to produce bagasse powder (Kamal et al., 2014)

Table (1) proximate composition of bagasse used for preparation of dietary fiber

\begin{tabular}{|c|c|}
\hline Items & $\begin{array}{l}\text { Proximate analysis }(g / 100 \text { g dry } \\
\text { matter) }\end{array}$ \\
\hline Protein & $\begin{array}{rr}2.1 \\
\end{array}$ \\
\hline Fiber & 34.4 \\
\hline
\end{tabular}


T. S. Abdel- ghany. .\& others.

\begin{tabular}{|r|r|}
\hline Ash & 1.38 \\
\hline Cellulose & 37.08 \\
\hline Hemicellulos & 21.25 \\
es & 6.42 \\
\hline Lignin & 1.0 \\
\hline Silica & 65.97 \\
\hline NDF & 44.72 \\
\hline ADF & 7.64 \\
\hline ADL &
\end{tabular}

\section{Animals, housing and experimental design}

The study involved 30 males growing White New Zealand (WNZ) rabbits of Aged 4 weeks with initial mean weight $(750 \pm 50 \mathrm{~g})$. Animals were divided into nine equal groups as shown in table (2). The study lasted two months period All animals were individually housed in galvanized wire cages $(50 \times 55 \times 39 \mathrm{~cm})$ provided with a feeder and automatic nipple drinker, and were kept under the same managerial conditions and all animals were weighed weekly.

Table (2). The experimental design used in vitro experiment

\begin{tabular}{|l|l|}
\hline (T1) & Basal diet \\
\hline (T2) & Received basal Diet supplemented with bagasse at level 3\% \\
\hline (T3) & Received basal Diet supplemented with bagasse at level 6\% \\
\hline (T4) & low dose of AFs + bagasse at level 3\% \\
\hline (T5) & low dose of AFs + bagasse at level 6\% \\
\hline
\end{tabular}

Table (3). Composition of ingredient feed rations for control and treated groups.

\begin{tabular}{|l|l|l|l|}
\hline Ingredients & Control & $\mathbf{T}_{2}$ & $\mathbf{T}_{3}$ \\
& & & \\
\hline Alfa alfa & 25.0 & $\mathbf{2 3 . 0}$ & $\mathbf{2 0 . 0}$ \\
\hline Wheat bran & $\mathbf{2 6 . 0}$ & $\mathbf{2 6 . 0}$ & $\mathbf{2 5 . 0}$ \\
\hline Barley grains ,Ground & $\mathbf{2 0 . 0}$ & $\mathbf{2 0 . 0}$ & $\mathbf{2 0 . 0}$ \\
\hline Soybean meal (44\% CP) & $\mathbf{1 3 . 5}$ & $\mathbf{1 4 . 0}$ & $\mathbf{1 5 . 0}$ \\
\hline Yellow corn, ground & $\mathbf{1 0 . 0}$ & $\mathbf{1 0 . 0}$ & $\mathbf{1 0 . 0}$ \\
\hline Wheat straw & $\mathbf{1 . 5}$ & - & - \\
\hline L- Methionine & $\mathbf{0 . 3 5}$ & $\mathbf{0 . 3 5}$ & $\mathbf{0 . 3 5}$ \\
\hline Line stone & $\mathbf{0 . 9}$ & $\mathbf{0 . 9}$ & $\mathbf{0 . 9}$ \\
\hline Di calcium phosphate & $\mathbf{1 . 9}$ & $\mathbf{1 . 9}$ & $\mathbf{0 . 3 5}$ \\
\hline Premix* & $\mathbf{0 . 5 0}$ & $\mathbf{0 . 5 0}$ & $\mathbf{0 . 5 0}$ \\
\hline Na Cl & $\mathbf{0 . 3 5}$ & $\mathbf{0 . 3 5}$ & $\mathbf{0 . 3 5}$ \\
\hline Bagasse & $\mathbf{0 . 0}$ & $\mathbf{3 . 0}$ & $\mathbf{6 . 0}$ \\
\hline Total (kg) & $\mathbf{1 0 0}$ & $\mathbf{1 0 0}$ & $\mathbf{1 0 0}$ \\
\hline Calculated values** & & & \\
\hline
\end{tabular}




\begin{tabular}{|l|l|l|l|}
\hline Crude protein \% & $\mathbf{1 7 . 1 1}$ & $\mathbf{1 7 . 2 4}$ & $\mathbf{1 6 . 9 2 7}$ \\
\hline ME, kcal/kg diet & $\mathbf{2 5 2 0}$ & $\mathbf{2 5 1 3}$ & $\mathbf{2 4 9 0}$ \\
\hline Crude fiber \% & $\mathbf{1 1 . 9 6 5}$ & $\mathbf{1 1 . 5 9}$ & $\mathbf{1 2 . 1 3 9}$ \\
\hline Ether extract \% & $\mathbf{2 . 5 4 4}$ & $\mathbf{2 . 4 9 0}$ & $\mathbf{2 . 4 0 5}$ \\
\hline Calcium \% & $\mathbf{1 . 1 7 3}$ & $\mathbf{1 . 1 4 7}$ & $\mathbf{1 . 1 0 9}$ \\
\hline Available phosphorus & $\mathbf{0 . 3 5 5}$ & $\mathbf{0 . 3 5 5}$ & $\mathbf{0 . 3 5 5}$ \\
\hline Lysine \% & $\mathbf{0 . 8 6 6}$ & $\mathbf{0 . 8 6 5}$ & $\mathbf{0 . 8 6 4}$ \\
\hline Methionine & $\mathbf{0 . 5 9 9}$ & $\mathbf{0 . 5 9 9}$ & $\mathbf{0 . 5 9 6}$ \\
\hline $\begin{array}{l}\text { Cost/kg of diet in L.E. } \\
\text { *** }\end{array}$ & $\mathbf{2 . 7 3}$ & $\mathbf{2 . 3 8}$ & $\mathbf{2 . 3 1}$ \\
\hline
\end{tabular}

*The premix (Vit. \& Min.) was added at a rate of $3 \mathrm{~kg}$ per ton of diet and supplied the following per $\mathrm{kg}$ of diet (as $\mathrm{mg}$ or I.U. per $\mathrm{kg}$ of diet): Vit. A 12000 I.U., Vit. D3 2000 I.U., Vit. E 40 mg, Vit. K3 4 mg, Vit. B1 3 mg, Vit. B2 6 mg, Vit. B6 $4 \mathrm{mg}$, Vit. B12 $0.03 \mathrm{mg}$, Niacine $30 \mathrm{mg}$, Biotine $0.08 \mathrm{mg}$, Pantothenic Acid $12 \mathrm{mg}$, Folic acid $1.5 \mathrm{mg}$, Choline chloride $700 \mathrm{mg}$, $\mathrm{Mn} 80 \mathrm{mg}, \mathrm{Cu} 10 \mathrm{mg}$, Se $0.2 \mathrm{mg}$, I $40 \mathrm{mg}$, Fe $40 \mathrm{mg}$, Zn $70 \mathrm{mg}$ and Co $0.25 \mathrm{mg}$.

**According to Feed Composition Tables for animal \& poultry feedstuffs used in Egypt (2001) and NRC (1994).

${ }^{* * *}$ According to market prices of the year 2017.

Live body weight (LBW): Individual body weight was taken weekly to the nearest $\pm 2.0 \mathrm{~g}$ by digital weighing scale (Mettler Toledo, Top Pan Sensitive Balance, J. Liang Int. Ltd. U.K.). The measurements were taken while the animals were held in a standing position.

Live body weight gain (LBWG) Individual LBWG for each rabbit was calculated at 2, 4,6,8,10 and 12 of experimental period by subtracting the initial LBW of a certain period from the final LBW of the same period, as follows:- $L B W G=\mathrm{W}_{2}-$ $\mathrm{W}_{1}$

Where: $\mathrm{W}_{1}=\mathrm{LBW}$ at the onset of a certain period.

$\mathrm{W}_{2}=\mathrm{LBW}$ at the end of the same period.

3.13.4. Feed intake (FI): Feed intake for each replicate under each treatment was weekly calculated, on a group basis, by subtracting the residual feed from the offered one. Average daily feed intake per rabbit was then calculated by using the following equations:

$\mathrm{FI} / \mathrm{rabbit} / \mathrm{day}=$

FI / replicate/week

No. of rabbits consumed feed daily during the week period

- Feed conversion ratio (FCR): Feed conversion ratio (FCR) (using the weight of mortality to correct FI data) weekly and whole experimental period was calculated for each replicate under each treatment and calculated as $\mathrm{kg}$ of feed used for producing one $\mathrm{kg}$ of body weight gain as follows:

FCR =Average feed intake $(\mathrm{kg})$ per rabbit / body weight gain $(\mathrm{kg})$ per rabbit. 


\section{RESULTS AND DISCUSSIONS.}

\subsection{Live body weight (LBW) (g) .}

Live body weight (LBW) (g) of growing rabbits as affected by different levels of dietary bagasse are presented in Table (4) fig (1). No significant differences were detected in the experimental groups initial LBW which ranged between $(745.83 \mathrm{~g})$ ( $\mathrm{T}_{1}$ and $\left.\mathrm{T}_{3}\right)$ to $(775.0 \mathrm{~g})$ $\left(\mathrm{T}_{5}\right)$. The results during experimental period showed insignificant differences among the experimental groups. At the final of experimental period, LBW of tested rabbit groups cleared insignificant differences where, group fed basal diet supplemented with bagasse at level 6\%

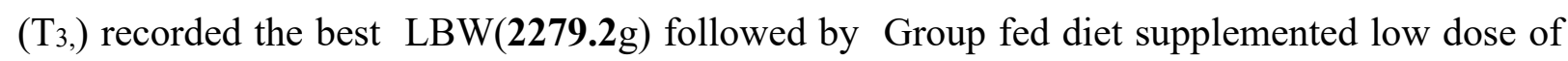
AFs + bagasse at level 6\% $\left(\mathbf{T}_{5}\right)$ being $(2177.5 \mathrm{~g})$,meanwhile, group fed basal diet (control ) $\left(\mathbf{T}_{\mathbf{1}}\right)$

\begin{tabular}{|c|c|c|c|c|c|}
\hline \multirow{2}{*}{ Groups } & \multicolumn{2}{|c|}{ bagasse } & \multicolumn{2}{|c|}{ Low aflatoxin dose } & \multirow[t]{2}{*}{ Sig } \\
\hline & $3 \%$ & $6 \%$ & $3 \%$ bagasse & $6 \%$ bagasse & \\
\hline
\end{tabular}

was the worst one being (2087 g) . These results were in agreement with those obtained by Esmail et al., (2016) who indicated that final body weight and feed intake of rabbits increased with increasing sugarcane bagasse levels. Also, Maidala et al., (2016) concluded that sugarcane bagasse can be used as a source of fibre in the diets of growing rabbits without deleterious effect with reduction in cost of production.

In this connection, Harriet (2003) reported that aflatoxins have been reported to cause digestive system effects such as diarrhea, vomiting, intestinal hemorrhage, and liver necrosis and fibrosis which may be causes LBW reduction.

Table 4. Live body weight (LBW) (g) as affected by different levels of dietary bagasse supplemented with Low aflatoxin dose (75.0ppb) . 


\begin{tabular}{|l|c|c|c|c|c|c|}
\hline Parameters & $T_{1}$ & \multicolumn{1}{|c|}{$T_{2}$} & $T_{3}$ & $T_{4}$ & $T_{5}$ & \\
\hline I.W.(g) & $745.83 \pm 35.62$ & $767.5 \pm 35.62$ & $745.83 \pm 35.62$ & $760 \pm 35.62$ & $775 \pm 35.62$ & NS \\
\hline LBW2 & $1130 \pm 44$ & $1123.33 \pm 44$ & $1112.5 \pm 44$ & $1081.67 \pm 44$ & $1176.67 \pm 44$ & NS \\
\hline LBW 4 & $1710 \pm 77.57$ & $1651.7 \pm 77.57$ & $1558.3 \pm 77.57$ & $1546.7 \pm 77.57$ & $1600 \pm 77.57$ & NS \\
\hline LBW 6 & $1982.5 \pm 97.15$ & $1973.3 \pm 97.15$ & $1994.2 \pm 97.15$ & $1847.5 \pm 97.15$ & $1971.7 \pm 97.15$ & NS \\
\hline LBW 8 & $2087 \pm 118.38$ & $2156.7 \pm 108.07$ & $2279.2 \pm 108.07$ & $\mathbf{2 1 4 6} \pm 118.38$ & $\mathbf{2 1 7 7 . 5} \pm 108.07$ & NS \\
\hline TLBW & $2087 \pm 118.38$ & $2156.7 \pm 108.07$ & $\mathbf{2 2 7 9 . 2} \pm 108.07$ & $\mathbf{2 1 4 6} \pm 118.38$ & $\mathbf{2 1 7 7 . 5} \pm 108.07$ & NS \\
\hline
\end{tabular}

$\mathrm{T} 1=$ Basal diet $; \mathrm{T} 2=$ basal Diet supplemented with bagasse at level 3\%, T3 = basal Diet supplemented with bagasse at level 6\%; T4: low dose of AFs + bagasse at level 3\%; T5: low dose of $\mathrm{AFs}+$ bagasse at level $6 \%$;

I W.(g) : Initial weight (g) ; LBW2: Live body weight after 2 weeks of experimental period ; LBW4: Live body weight after 4 weeks of experimental period ; LBW6 : Live body weight after 6 weeks of experimental period ; LBW8: Live body weight after 8 weeks of experimental period ; TLBW: Total Live body weight the experimental period . NS = not significant $\mathrm{SE}=$ standard error

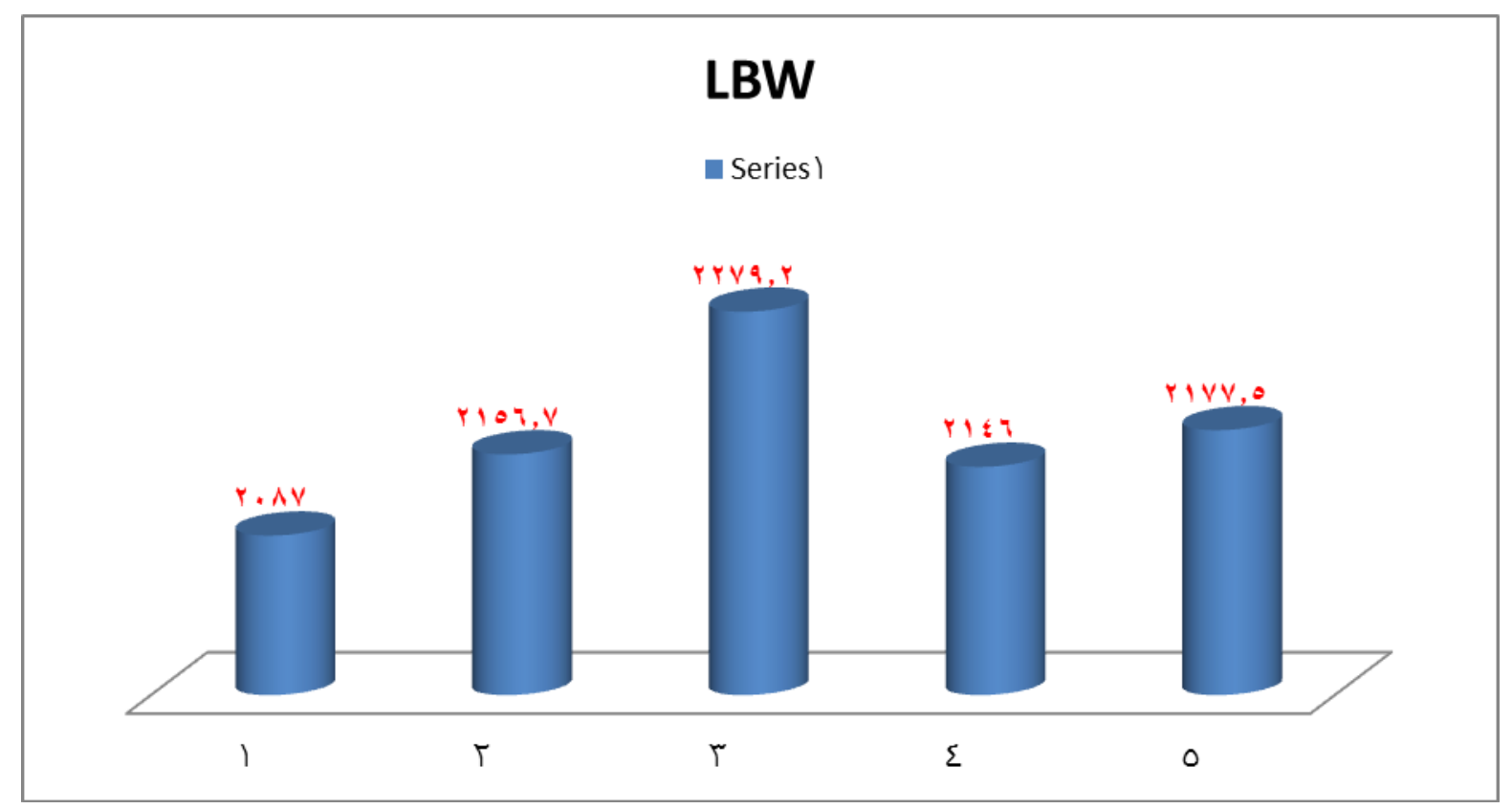

Fig. (1) Total live body weight (TLBW) (g) as affected by different levels of dietary bagasse supplemented with Low aflatoxin dose (75.0ppb)

\subsection{Live body weight gain (LBWG) (g):}

Live body weight gain (LBWG) (g) of growing rabbits as affected by different levels of dietary bagasse are illustrated in Table (5) and fig.( 2 ). Data of LBWG (g) after the second week cleared that group fed dietary bagasse at level $6 \%$ and low dose of AFs (75.0ppb) $\left(\mathrm{T}_{5}\right)$ achieved significantly $(\mathrm{P}<0.05)$ the highest (LBWG) 
value $(219.17 \mathrm{~g})$ meanwhile, group fed dietary bagasse at level $3 \%$ and low dose of AFs (75.0ppb) $\left(\mathrm{T}_{4}\right)$ recorded the lowest one (130).

In this concern, Maidala et al., (2016) reported that the rabbit is also a very

\begin{tabular}{|c|c|c|c|c|c|c|}
\hline \multirow{4}{*}{$\begin{array}{l}\text { Groups } \\
\text { Paramete } \\
\text { rs }\end{array}$} & \multirow{3}{*}{ Control } & \multicolumn{4}{|l|}{ Treatment } & \multirow[t]{4}{*}{ Sig. } \\
\hline & & \multicolumn{2}{|l|}{ bagasse } & \multicolumn{2}{|c|}{$\begin{array}{ll}\text { Low } & \text { aflatoxin } \\
\text { dose(75.0ppb) }\end{array}$} & \\
\hline & & $3 \%$ & $6 \%$ & $\begin{array}{l}3 \% \\
\text { bagasse }\end{array}$ & $\begin{array}{l}6 \% \\
\text { bagasse } \\
\end{array}$ & \\
\hline & $\mathbf{T}_{1}$ & $\mathbf{T}_{2}$ & $\mathbf{T}_{3}$ & $\mathbf{T}_{4}$ & $T_{5}$ & \\
\hline $\begin{array}{l}\text { LBWG } \\
2\end{array}$ & $\begin{array}{l}205^{a b} \pm 21 \\
12\end{array}$ & $\begin{array}{l}170^{\mathrm{abc}} \pm 21.1 \\
2\end{array}$ & $\begin{array}{l}164.17^{\mathrm{abc}} \pm 21 \\
12\end{array}$ & $130^{c} \pm 21.12$ & $\begin{array}{l}219.17^{a} \pm 21 \\
12\end{array}$ & * \\
\hline $\begin{array}{l}\text { LBWG } \\
4\end{array}$ & $\begin{array}{l}249.17^{\mathrm{a}} \pm 2 \\
8.8\end{array}$ & $\begin{array}{l}240.83^{a} \pm 28 \\
79\end{array}$ & $\begin{array}{l}193.33^{a} \pm 28.7 \\
9\end{array}$ & $\begin{array}{l}177.5^{a} \pm 28.7 \\
9\end{array}$ & $\begin{array}{l}172.5^{a} \pm 28.7 \\
9\end{array}$ & * \\
\hline $\begin{array}{l}\text { LBWG } \\
6\end{array}$ & $\begin{array}{l}110.83^{b} \pm 3 \\
5.5\end{array}$ & $\begin{array}{l}158.33^{b} \pm 35 \\
51\end{array}$ & $\begin{array}{l}155.83^{b} \pm 35.5 \\
1\end{array}$ & $\begin{array}{l}200.83^{a b} \pm 3 \\
5.5\end{array}$ & $\begin{array}{l}280.83^{a} \pm 35 \\
51\end{array}$ & * \\
\hline$\overline{\text { LBWG }}$ & $44^{c} \pm 22.65$ & $45^{b c} \pm 20.68$ & $85^{\mathrm{abc}} \pm 20.68$ & $137^{a} \pm 22.65$ & $26.67^{c} \pm 20.6$ & $*$ \\
\hline
\end{tabular}

efficient converter of feed to animal protein and the meat is very nutritious, easily digested, extremely low in cholesterol and sodium and contains more protein and less fat, when compared to various other meats. The advantages projected include the high reproductive rate, rapid maturity, high genetic potential, efficient feed utilization, limited competition with humans for food and high quality nutritious meat

Table 6. Live body weight gain (LBWG) (g) as affected by different levels of dietary bagasse supplemented with Low aflatoxin dose (75.0ppb) . 


\begin{tabular}{|l|l|l|l|l|l|l|}
\hline 8 & & & & & 8 & \\
\hline TG & $1334 \pm 115$. & $1389.1^{\mathrm{a}} \pm 10$ & $1533.33 \pm 105$. & $1398 \pm 115.2$ & $1402 .^{\mathrm{a}} \pm 105$. & \\
& 24 & 5.2 & 2 & 4 & 2 & $*$ \\
\hline
\end{tabular}

a, b ......c values within a row with different superscripts significantly different $(\mathbf{p}<\mathbf{0 . 0 5})$.

$*=\mathrm{p}<0.05 \quad \mathrm{NS}=$ not significant $\mathrm{SE}=$ standard error $\quad \mathbf{T}_{\mathbf{1}}=$ Basal diet $; ; \mathbf{T}_{\mathbf{2}}=$ basal Diet supplemented with bagasse at level $3 \%, \mathbf{T}_{\mathbf{3}}=$ basal Diet supplemented with bagasse at level $6 \% ; \mathbf{T}_{4}$ : low dose of AFs + bagasse at level $3 \% ; \mathbf{T}_{5}$ : low dose of AFs + bagasse at level 6\%; LBWG 2: Live body weight gain after 2 weeks of experimental period; LBW4: Live body weight gain after 4 weeks of experimental period ; LBW6 : Live body weight gain after 6 weeks of experimental period ; LBWG8: Live body weight gain after 8 weeks of experimental period ; TG: Total Live body weight gain the experimental period .

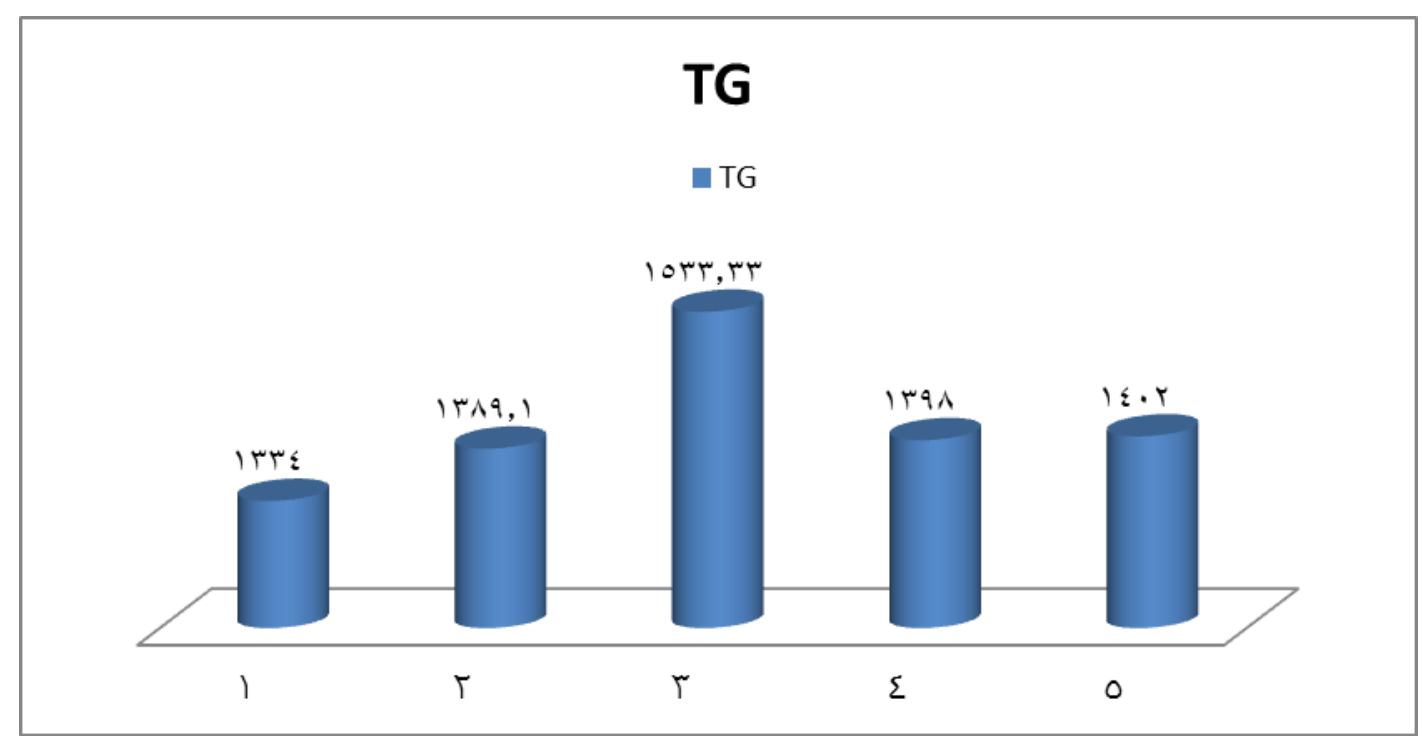

Fig. (2) Total live body weight gain (TLBWG) (g) as affected by different levels of dietary bagasse supplemented with Low aflatoxin dose (75.0ppb)

Feed intake (FI) (g)

Results feed intake (g) (FI) of growing rabbits as affected by different levels of dietary bagasse are presented in Table (7) fig ( 3 ). Data indicated that Rabbit groups fed Basal diet ; 3\% bagasse and 3\% bagasse with Low aflatoxin dose (75.0ppb) significantly $\mathrm{P}<0.05$ consumed more feed than Rabbit groups fed $6 \%$ bagasse or $6 \%$ bagasse with Low aflatoxin dose (75.0ppb) after two ;4 and 6weeks of experimental period ( Table 7) . After 8 weeks of experimental period, rabbit groups fed 3 or $6 \%$ bagasse and groups fed 3or $6 \%$ bagasse with Low aflatoxin dose (75.0ppb) significantly $(\mathrm{P}<0.05)$ consumed more feed than control group. Meanwhile, total feed intake showed that rabbit groups fed $6 \%$ bagasse and groups fed $6 \%$ bagasse with Low aflatoxin dose $(75.0 \mathrm{ppb})$ significantly $(\mathrm{P}<0.05)$ consumed feed less than control 
and other experimental groups. These results are agree with those obtained by Ismail et al., (2016) who indicated that final body weight and feed intake of rabbits increased with increasing sugarcane bagasse levels. The highest performance index could be observed with rabbits fed (sugarcane bagasse replace to $50 \%$ berseem hay) diet and control diets ( $\%$ sugarcane bagasse). Also, Guilherme et al., (2015) stated that sugarcane bagasse is a very promising raw material for the production of glucose, xylose, ethanol and methane.

Table 7. Feed intake (g) as affected by different levels of dietary bagasse supplemented with Low aflatoxin dose (75.0ppb).

a, b ...... values within a row with different superscripts significantly different $(\mathbf{p}<\mathbf{0 . 0 5})$.

$*=\mathrm{p}<0.05 \quad \mathrm{NS}=$ not significant $\mathrm{SE}=$ standard error $\quad \mathbf{T}_{\mathbf{1}}=$ Basal diet $; \mathbf{T}_{\mathbf{2}}=$ basal Diet supplemented with bagasse at level $3 \%, \mathbf{T}_{\mathbf{3}}=$ basal Diet supplemented with bagasse at level $6 \% ; \mathbf{T}_{4}$ : low dose of AFs + bagasse at level $3 \% ; \mathbf{T}_{5}$ : low dose of AFs + bagasse at level $6 \%$; FI2: Feed Intake after 2 weeks of experimental period ; FI4: Feed Intake after 4 weeks of experimental period ; FI6 : Feed Intake after 6 weeks of experimental period ; FI8: Feed Intake after 8 weeks of experimental period ; TFI: Total Feed Intake of experimental period .

\begin{tabular}{|c|c|c|c|c|c|c|}
\hline \multirow{4}{*}{$\begin{array}{l}\text { Grou } \\
\text { ps } \\
\text { Parame } \\
\text { ers }\end{array}$} & \multirow{3}{*}{ Basal diet } & \multicolumn{4}{|l|}{ Treatments } & \multirow{3}{*}{$\begin{array}{l}\text { Sig } \\
\text {. }\end{array}$} \\
\hline & & \multicolumn{2}{|l|}{ bagasse } & \multicolumn{2}{|c|}{ Low aflatoxin dose } & \\
\hline & & $3 \%$ & $6 \%$ & $\begin{array}{l}3 \% \\
\text { bagasse }\end{array}$ & $\begin{array}{l}6 \% \\
\text { bagasse }\end{array}$ & \\
\hline & T1 & $\mathbf{T 2}$ & T3 & T4 & T5 & \\
\hline FI2 & $\begin{array}{l}536.67^{a} \pm 23 . \\
2\end{array}$ & $535^{\mathrm{a}} \pm 23.2$ & $\begin{array}{l}499.17^{a b} \pm 23 \\
.2\end{array}$ & $\begin{array}{l}551.67^{\mathrm{a}} \pm 23 \\
.2\end{array}$ & $\begin{array}{l}504.17^{a b} \pm 23 \\
.2\end{array}$ & $*$ \\
\hline FI4 & $\begin{array}{l}979.17 \\
a_{ \pm 87.24}\end{array}$ & $\begin{array}{l}852.5^{a b} \pm 87 \\
24\end{array}$ & $\begin{array}{l}852.5^{a b} \pm 87 \\
24\end{array}$ & $\begin{array}{l}684.17^{b} \pm 87 \\
.2\end{array}$ & $\begin{array}{l}760.83^{a b} \pm 87 \\
.24\end{array}$ & $*$ \\
\hline FI6 & $\begin{array}{l}702.5^{b} \pm 65.3 \\
1\end{array}$ & $\begin{array}{l}837.5^{a b} \pm 65 . \\
31\end{array}$ & $\begin{array}{l}909.17^{a b} \pm 65 \\
.31\end{array}$ & $\begin{array}{l}790^{a b} \pm 65.3 \\
1\end{array}$ & $\begin{array}{l}889.17^{a b} \pm 65 \\
.31\end{array}$ & $*$ \\
\hline FI8 & $\begin{array}{l}139.38^{b} \pm 31 \\
04\end{array}$ & $240^{a} \pm 25.34$ & $285^{a} \pm 27.76$ & $\begin{array}{l}300^{\mathrm{a} \pm} \pm 27.7 \\
6\end{array}$ & $240^{a} \pm 25.34$ & $*$ \\
\hline TFI & $\begin{array}{l}5147.88 \pm 35 \\
5.99\end{array}$ & $\begin{array}{l}5277.5 \pm 29 \\
0.67\end{array}$ & $\begin{array}{l}5285 \pm 318.4 \\
1\end{array}$ & $\begin{array}{l}4951.5 \pm 318 \\
.4\end{array}$ & $\begin{array}{l}5135.83 \pm 29 \\
0.7\end{array}$ & NS \\
\hline
\end{tabular}




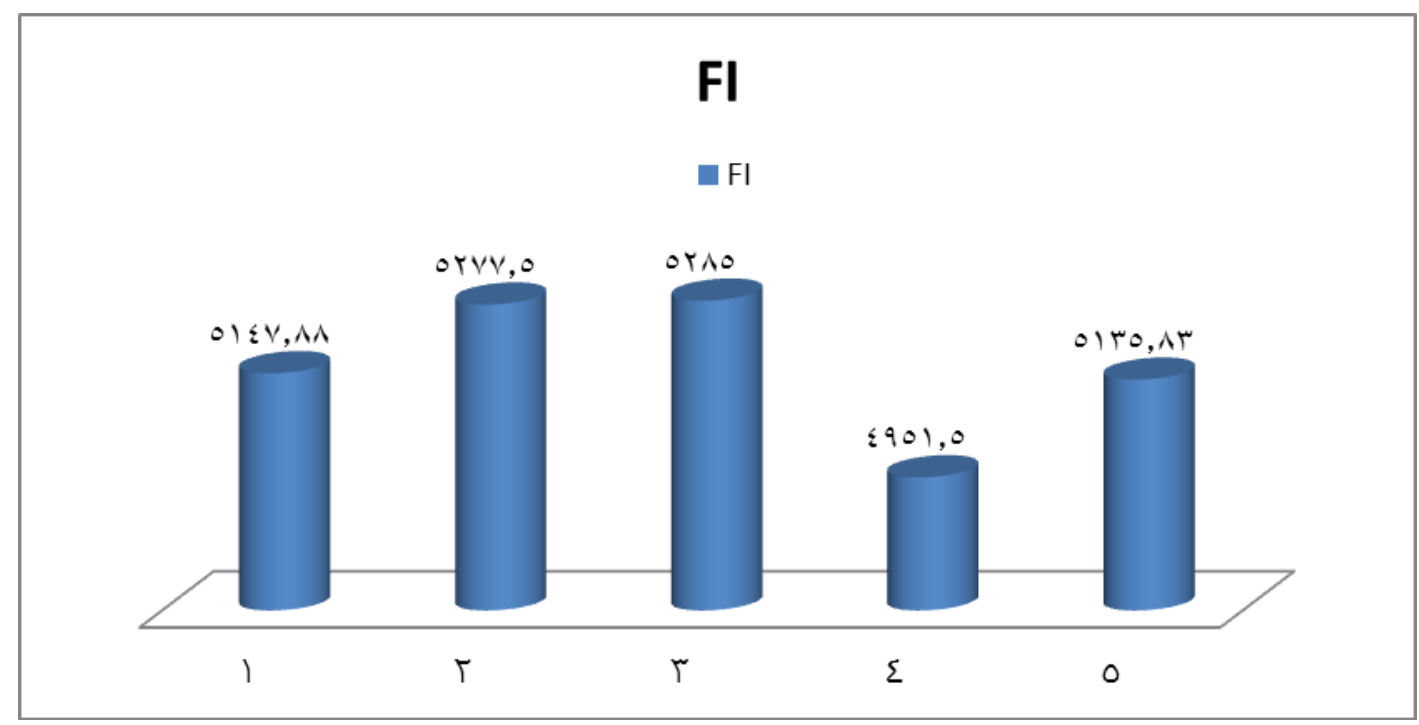

Fig. (3) Feed intake (g) as affected by different levels of dietary bagasse supplemented with Low aflatoxin dose (75.0ppb).

\section{Feed conversion ratio (FCR) (g)}

Results of feed conversion ratio (FCR) of growing rabbits as affected by different levels of dietary bagasse and aflatoxin doses are presented in Table (8) and fig (4). After two weeks of experiment, the better FCR value was significantly $(p<0.05)$ detected with rabbit group fed $6 \%$ bagasse with low aflatoxin dose (75.0ppb) being (2.38) compared to control and other experimental groups. No significant differences $(\mathrm{p}<0.05)$ were found among $\mathrm{FCR}_{6}$ and TFCR .these results means that different levels of dietary bagasse up to $3 \%$ adsorb the low aflatoxin dose (75.0ppb) and improved feed efficiency. These results are in agreement with those obtained by Ismail et al., (2016) who indicated that final body weight and feed intake of rabbits increased with increasing sugarcane bagasse levels. The highest performance index could be observed with rabbits fed (sugarcane bagasse replace to $50 \%$ berseem hay) diet and control diets ( $0 \%$ sugarcane bagasse).

Sugarcane bagasse is principally composed of cellulose, hemi-cellulose and lignin (about 40\%, 34\% and 20\% respectively on dry wright basis ) (Garg et al , 2004) . Cellulose is a crystalline homo - polymer of glucose with p-4 glycosidic linkage and intermolecular hydrogen bonds. Hemicelluloses is a heteropolymer of mainly xylose with p-4 linkage with other substances of acetyl feruoyl and glycouronyl groups. 
Lignin is a polyhydroxy compound. It offer a numbers of hydroxyl sites for binding (Abo Haggar, 2006).

\begin{tabular}{|c|c|c|c|c|c|c|}
\hline \multirow{3}{*}{$\begin{array}{l}\text { Groups } \\
\text { Parameters }\end{array}$} & \multirow{3}{*}{$\begin{array}{l}\text { Basal } \\
\text { diet }\end{array}$} & \multicolumn{4}{|c|}{ Treatments } & \multirow{4}{*}{$\begin{array}{l}\text { Si } \\
\text { g. }\end{array}$} \\
\hline & & \multicolumn{2}{|l|}{ bagasse } & \multicolumn{2}{|c|}{ Low aflatoxin dose } & \\
\hline & & $3 \%$ & $6 \%$ & $\begin{array}{l}3 \% \\
\text { bagasse }\end{array}$ & $\begin{array}{l}6 \% \\
\text { bagasse }\end{array}$ & \\
\hline & T1 & $\mathbf{T 2}$ & T3 & T4 & T5 & \\
\hline FCR2 & $\begin{array}{l}2.74^{b} \pm 0.5 \\
2\end{array}$ & $3.5^{a b} \pm 0.52$ & $\begin{array}{l}3.56^{a b} \pm 0 \\
52\end{array}$ & $4.61^{\mathrm{a}} \pm 0.52$ & $2.38^{b} \pm 0.52$ & $*$ \\
\hline FCR4 & $\begin{array}{l}4.01^{a b} \pm 0 . \\
57\end{array}$ & $\begin{array}{l}3.58^{a b} \pm 0.5 \\
7\end{array}$ & $\begin{array}{l}4.91^{a b} \pm 0 . \\
57\end{array}$ & $\begin{array}{l}3.75^{a b} \pm 0.5 \\
7\end{array}$ & $5.14^{\mathrm{a}} \pm 0.57$ & $*$ \\
\hline FCR6 & $\begin{array}{l}7.27 \pm 2.0 \\
9\end{array}$ & $8.95 \pm 2.09$ & $\begin{array}{l}8.17 \pm 2.0 \\
9\end{array}$ & $6.88 \pm 2.09$ & $3.29 \pm 2.09$ & $\mathbf{N S}$ \\
\hline FCR8 & $\begin{array}{l}4.37^{b} \pm 2.1 \\
2\end{array}$ & $\begin{array}{l}11.54^{a} \pm 1.7 \\
3\end{array}$ & $\begin{array}{l}3.05^{b} \pm 2.1 \\
2\end{array}$ & $2.51^{b} \pm 2.12$ & $\begin{array}{l}8.75^{a b} \pm 1.9 \\
1\end{array}$ & $*$ \\
\hline TFCR & $\begin{array}{l}3.22 \pm 1.1 \\
2\end{array}$ & $3.84 \pm 0.92$ & $\begin{array}{l}3.42 \pm 1.1 \\
2\end{array}$ & $3.6 \pm 1.0$ & $6.19 \pm 0.92$ & NS \\
\hline
\end{tabular}

Table 8. Feed conversion ratio (FCR) as affected by different levels of dietary bagasse supplemented with Low aflatoxin dose (75.0ppb).

a ......b values within a row with different superscripts significantly different $(\mathrm{p}<\mathbf{0 . 0 5})$.

$*=\mathrm{p}<0.05 \quad \mathrm{NS}=$ not significant $\quad \mathrm{SE}=$ standard error $\quad \mathbf{T}_{\mathbf{1}}=$ Basal diet $; \mathbf{T}_{\mathbf{2}}=$ basal Diet supplemented with bagasse at level $3 \%, \mathbf{T}_{\mathbf{3}}=$ basal Diet supplemented with bagasse at level $6 \% ; \mathbf{T}_{4}$ : low dose of AFs + bagasse at level $3 \% ; \mathbf{T}_{5}$ : low dose of AFs + bagasse at level 6\%; FCR2: Feed Conversion ratio after 2 weeks of experimental period; FCR4: Feed Conversion ratio after 4 weeks of experimental period ; FCR6: Feed Conversion ratio after 6 weeks of experimental period ; FCR2: Feed Conversion ratio after 8 weeks of experimental period ; TFCR: Total Feed Conversion ratio of experimental period . 


\section{Con. Of AF(ppb)}

\subsection{8}

\section{FCR}

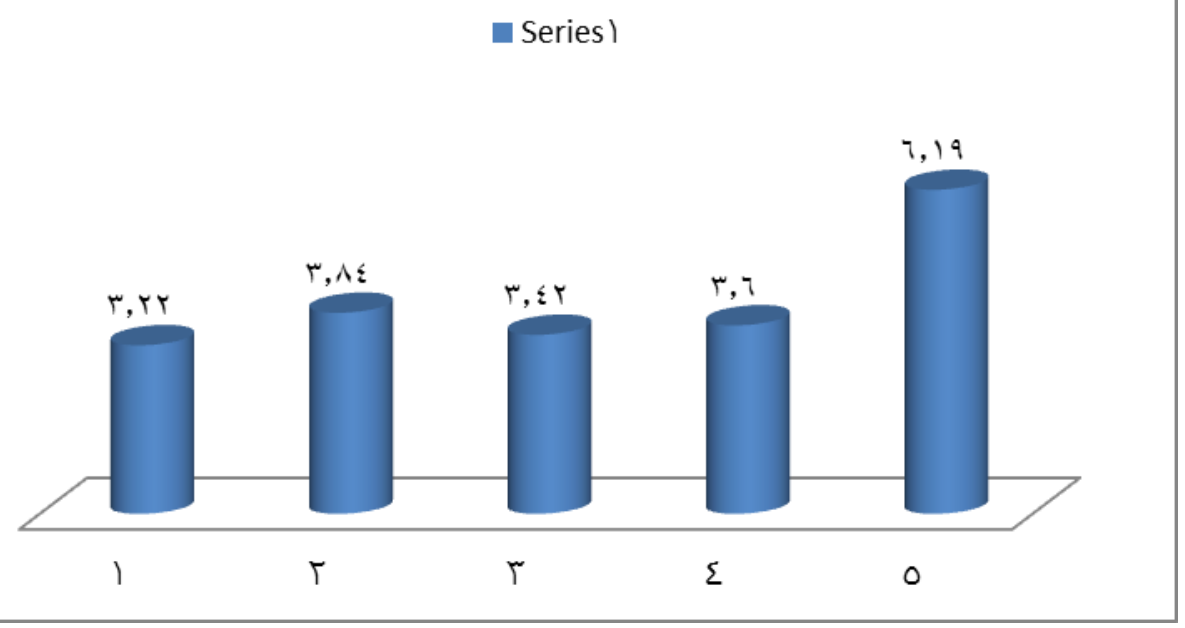

Fig. (3) Feed conversion ratio (FCR) as affected by different levels of dietary bagasse supplemented with Low aflatoxin dose (75.0ppb)

\section{In vitro experiment: Adsorption of Aflatoxins by bagasse}

This study was conducted to determine the efficacy of bagasse and its ability to adsorb TAF, under the influence of several factors in cluding : adsorbent level (3and 6\% w/v ), contact time (shaking )1,2, and $3 \mathrm{hrs}$, TAF concentration (105.8 ppb)

Table 9 . Concentration of remaining TAF Treated by bagasse as affected by different Treatment. 
T. S. Abdel- ghany. .\& others.

\begin{tabular}{|l|l|l|l|}
\hline \multicolumn{2}{|l|}{ Treatment } & \multicolumn{2}{l|}{ Shaking } \\
\hline $\begin{array}{l}\text { Bagasse Addition W/V } \\
\%\end{array}$ & 1 hr & $2 \mathrm{hr}$ & $3 \mathrm{hr}$ \\
\hline 3 & 95.26 & 95.92 & 96.21 \\
\hline 6 & 97.10 & 97.63 & 98.10 \\
\hline
\end{tabular}

Table 10. Percent of bounding TAF using bagasse as affected by different Treatment.

\begin{tabular}{|l|l|l|l|}
\hline Con. of. TAF(ppb) & \multicolumn{2}{l|}{105.58} & \multicolumn{2}{l|}{} \\
\hline Treatment & \multicolumn{2}{|l|}{ Shaking } & $3 \mathrm{hr}$ \\
\hline $\begin{array}{l}\text { Bagasse Addition } \\
\text { W/V \% }\end{array}$ & $1 \mathrm{hr}$ & $2 \mathrm{hr}$ & \\
\hline 3 & & & \\
\hline 6 & $5.0^{\mathrm{a}}$ & $4.3^{\mathrm{ab}}$ & $4.0^{\mathrm{ab}}$ \\
\hline
\end{tabular}

The physical methods used for the removal of mycotoxins focused in using nutritionally inert sorbent in the diet that can sequester mycotoxins and reduce their adsorption from the gastrointestinal tract. The utilization of mycotoxins - binding adsorbent is the most applied way to protect animals against the harmful effects of contaminated feed. Sugarcane bagasse is principally composed of cellulose, hemicellulose and lignin (about 40\%, 34\% and 20\% respectively on dry wright basis ) (Garg et al ,. 2004) .

Cellulose is a crystalline homo - polymer of glucose with p-4 glycosidic linkage and intermolecular hydrogen bonds. Hemicelluloses is a heteropolymer of mainly xylose with p-4 linkage with other substances of acetyl feruoyl and glycouronyl groups. Lignin is a polyhydroxy compound. It offer a numbers of hydroxyl sites for binding (Abo Haggar, 2006).

Adsorption abilities ranged from 94.63-98.10 \% the highest adsorption capacity was observed when using $6 \%$ bagasse and $3 \mathrm{hr}$ shaking time at low TAF concentration, while the lowest value of binding was obtained at level $3 \%$ bagasse and $1 \mathrm{hr}$ shaking time and high TAF concentration.

These results almost in agreement with Munagapati et al. (2018) who concluded high ability of banana peel powder as an adsorbent to remove of anionic dyes from aqueous solution. They also concluded that the adsorption increase by 
increasing contact time. This is because banana peel has an irregular and porous surface which is adequate for adsorption. Oyewo et al. (2016) indicated that nanostructured banana peels is a potential adsorbent for the removal of radioactive substances from aqueous solution and also from real mine water. Vekiru et al. (2015) studied the in vitro binding assessment and in vivo efficacy of several adsorbents against aflatoxin $\mathrm{B}_{1}$ and concluded the ability of adsorbents to ameliorate aflatoxin induced effects in poultry basically correlated with the in vitro findings.

\section{Conclusions:}

The study concluded that using dietary $6 \%$ bagasse with Low aflatoxin dose (75.0ppb) in growing rabbit diets significantly improve growth performance and have Adsorption ability at low TAF concentration. ranged from 94.63-98.10\% the highest adsorption capacity was observed when using $6 \%$ bagasse and $3 \mathrm{hr}$ shaking time at low TAF concentration, while the lowest value of binding was obtained at level $3 \%$ bagasse and $1 \mathrm{hr}$ shaking time and high TAF concentration.

\section{REFERENCE}

Abo Haggar, A. (2006). Use of bagasse as adsorbent material for the removal of total aflatoxins (in vitro). J Agric.Sci. Mansoura Univ., 31: 4205-4212,

Amin, N. (2011). Use of bagasse ash in concrete and its impact on the strength and chloride resistivity. J. Mate Civ. Eng., 23(5), 717-720.

Cardona T.D., LLangantileke S.G., Noomhorm A. (1991). Aflatoxin research on grain in Asia: its problems and possible solutions. In: Semple, R.L., Frio, A.S., Hicks, P.A., Lozare, J.V. (ed). Mycotoxin prevention and control in foodgrains. FAO, Bangkok, pp. 309-322. Evaluatio of composition, Characterization and enzymatic hydrolysis of pretedted sugar cane bagasse .Vol. 32, No. 01, pp. 23 - 33, January March, 2015

Christensen, C.M. 1965. Fungi in Cereal Grains and Their Mycotoxins in Foodstuffs. MIT Press, Cambridge, Massachusetts.

Diener, U.L. and Davis, N.D. 1968. Effect of environment on aflatoxins production in freshly dug peanuts. Tropical Science, 10: 22- 28.

Feed Composition Tables for Animal and Poultry Feedstuffs Used In Egypt (2001). Technical bulletin. No.1, Central Lab for Feed and Food, Ministry of Agriculture, Egypt.

Garg,V.K., Amita, M., Kumar, R. and Gupta, R. (2004). Basic dye (methylene blue) removal from simulated waste water by adsorption using Indian Rosewood sawdust: a timber industry waste. Dyes Pigments . 63:243-250.

Guilherme A.A., Dantas P. V. F., Santos E. S., Fernandes F. A. N. and Macedo G. R. 
Gursoy, N., et al. (2008). Changes in spontaneous contractions of rat ileum by aflatoxin in vitro. Food Chemistry and Toxicology, 46(6), 21242127.

Harriet, A. M. (2003). Is indoor mold contamination a threat to health? Journal of Environmental

Hegazy R.A. and El Faramawy A.A , 2001 .Substitution of sugar cane bagasse in the chicken diet and immune response Nahrung/Food 45 (2001) No. 5 , pp. $364 \pm 367$

Hesseltine, C.W., Shotwell, O.L., Ellis, J.J. and Stubblefield, R.D. 1966. Aflatoxin formation by Aspergillus flavus. Bacteriology Review, 30: 795- 805.

Ismail F.S.A., Elgogry M.R., Morsy W.A., EL-Tahan H.M (2016). EFFECT OF USING SUGARCANE BAGASSE WITH OR WITHOUT ENZYMES IN RABBIT DIETS ON GROWTH PERFORMANCE OF GROWING RABBITSWorld Rabbit Science Association Proceedings $11^{\text {th }}$ World Rabbit Congress- Jone 15-18,2016.

JoséC.del Río , Alessandro G. Lino , Jorge L. Colodette , Claudio F. Lima , Ana Gutiérrez, Angel T. Martínez, Fachuang Lu, John Ralph, Jorge Rencoret (2015). Differences in the chemical structure of the lignins from sugarcane bagasse and straw. Biomass and Bioenergy 81 (2015) 322- 338.

Kamal G. Nath (2011) Utilization of sugarcane bagasse fiber in functional food formulations . Master of science. University of Agricultural Sciences, Bengaluru, 2011.

Kumar M., Dwivedi P., Sharma A.K., Telang A.G., Patil R.D., Singh N.D. (2008). Immunotoxicity of ochratoxin a and citrinin in New zealand white rabbits. World Rabbit Sci., 16: 7-12.

Maidala, A. and Istifanus, J.A (2012).The role of micro livestock in alleviating protein deficiency and poverty reduction in Nigeria being a paper presented at the second school of vocational and technical education National Conference Held at College of Education Azare from 4-8 th June, 2012.

Maidala, A. Dahuwa, T.N., Haruna, J. (2016)Nutritional Evaluation of Human Used Sugar Cane Bagasse as a Source of Fibre on Growth Performance and Carcass Characteristics of RabbitsInternational Journal of Geography and Environmental Management ISSN 2504-8821 Vol. 2 No.1

Makkar H.P.S., Singh B. (1991). Aflatoxicosis in rabbits. J. Appl. Rabbit Res., 14: 218-221.

Munagapati, V. S.; Yarramuthi, V.; Kim, Y.; Lee K. M. and Kim, D. (2018). Removal of anionic dyes (Reactive Black 5 and Congo red) from aqueous solutions using Banana Peel Powder as an adsorbent. Ecotoxicology and Environmental Safety 148: 601-607.

NRC, (1994). Nutrient Requirements of Poultry. 9th rev. ed. Nat 1. Acad. Press. Washington. 
Oyewo, O.A.; Onyango, M.S. and Wolkersdorfer, C. (2016). Application of banana peels nanosorbent for the removal of radioactive minerals from real mine water. Journal of Environmental Radioactivity 164: 369-376.

Raper K.B. and Fennell, D.I. 1965. The Genus Aspergillus. Williams and Wilkins Company. Baltimore MD, Maryland, pp 1-686

Raper K.B. and Fennell, D.I.( 1965). The Genus Aspergillus. Williams and Wilkins Company. Baltimore MD, Maryland, pp 1-686

Saladino, F.; Bordin, K.; Manyes, L.; Luciano, F.B.; Fernandez-Franzon, J.M. and Meca, G. (2016). Reduction of the aflatoxins $B_{1}, B_{2}, G_{1}$ and $G_{2}$ in Italian piadina by isothiocyanates. J. Sci. Technol.70: 302-308.

Thrasher, J. D. (2012). Aflatoxicosis in animals. Aflatoxins and Health,www.alphaboostjuice.com/AFLATOXICOSIS_IN_ANIMALS. pdf.

USAID. (2012). Aflatoxin: A Synthesis of the Research in Health, Agriculture and Trade. Feed the Future: The Office of Regional Economic Integration USAID East Africa Regional Mission Nairobi, Kenya, www.eastafrica.usaid.gov/...esearch_in_Health_Agriculture_ and_Trade/pdf, 10-15.

Vekiru, E.; Fruhauf, S., Rodrigues; I., Ottner, F.; Krska, R., Schatzmayr, G.; Ledoux, D.R.; Rottinghaus, G. E. and Bermudez, A. J. (2015). In vitro binding assessment and in vivo efficacy of several adsorbents against aflatoxin B1. World Mycotoxin Journal, 8:477- 488.

Wu, F., \& Khlangwiset, P. (2010). Health economic impacts and costeffectiveness of aflatoxin reduction strategies in Africa: Case studies in biocontrol and postharvest in- terventions. Food Additives \& Contaminants, 27, 496-509. 